\title{
Keberfungsian Model ABC Tschudi untuk Internalisasi Budaya Belajar Mahasiswa
}

\author{
Andi Mappiare-AT*, Lutfi Fauzan \\ Jurusan Bimbingan dan Konseling, Fakultas Ilmu Pendidikan, Universitas Negeri Malang \\ Jl. Semarang No. 5, Malang, Jawa Timur, Indonesia, 65145 \\ *Penulis koresponden, e-mail: andi.mappiare.fip@um.ac.id
}

Artikel diterima: 7 Februari 2019; direvisi: 19 Mei 2019; disetujui: 24 Mei 2019

\begin{abstract}
This research aimed to find: (1) the difficulties possibly faced by subjects in managing personal construct when filling Tschudi ABC format; (2) key personal construct recognized by subjects in their present and desired positions; (3) the results of subjects' learning culture internalization to the implementation of Tschudi ABC Model. This study used a qualitative approach with the type of Classroom Action Research, the empirical phenomenological variant. The observed subjects were determined by purposive sampling, taken from the students of Multicultural Counseling class. The research informants were determined through snowballing. The data collection was conducted via a medium participatory observation and in-depth interview. The individual analysis was employed in the form of dynamic analysis of the research subjects' individual personality. This research found that: (1) there was a difficulty in the form of contradiction and disparity in personal construct management. According to the subjects, compromise and synchronization of thoughts and attitudes were effective in settling the self-denial and gap; (2) The tendency of the change of subjects' key personal construct was intentional accompanied by discursive awareness versus withdrawal and stagnant. There was a change of key personal construct to the more productive and non-productive orientation; (3) The function of "good news" versus "bad news" was very strong in the internalization of subjects' learning culture. Providing "good news" (positive feedback) gave rise to more non-formal and affective internalization of learning culture with the purpose stated consciously and obviously, as well as concrete, clear, decisive, and straightforward plans.
\end{abstract}

Keywords: group guidance; learning culture; good news; Tschudi ABC Model

Abstrak: Tujuan penelitian ini adalah menemukan: (1) kemungkinan kesulitan yang dihadapi oleh subjek dalam kelola konstruk pribadi ketika mengisi format ABC Tschudi; (2) konstruk pribadi kunci yang dikenali oleh para subjek dalam posisi sekarang dan posisi yang dituju; (3) hasil internalisasi budaya belajar subjek atas penerapan Model ABC Tschudi. Penelitian ini menggunakan pendekatan kualitatif tipe penelitian tindakan kelas, varian fenomenologi empirik. Subjek terteliti ditetapkan melalui teknik "purposive sampling", para peserta kuliah dalam kelas Konseling Multibudaya. Informan penelitian ditetapkan secara snowballing. Pengumpulan data melalui observasi berpartisipasi medium dan wawancara mendalam. Digunakan unit analisis individual yaitu analisis dinamika konstruk pribadi perseorangan dari subjek penelitian. Temuan penelitian ini adalah: (1) ada kesulitan berupa pertentangan dan kesenjangan dalam kelola konstruk pribadi. Kompromi dan sinkronisasi pemikiran serta sikap merupakan cara efektif yang dinyatakan oleh subjek untuk mengatasi pertentangan dan kesenjangan dalam diri; (2) kecenderungan perubahan konstruksi pribadi kunci subjek adalah intensional disertai kesadaran diskursif versus withdrawal dan stagnan. Ada perubahan konstruk pribadi kunci ke arah yang lebih produktif dan ada yang ke arah non-produktif; (3) sangat kuat fungsi "kabar gembira" versus "bukan kabar gembira" dalam internalisasi budaya belajar subjek. Pemberian "kabar gembira" (balikan positif) menimbulkan internalisasi budaya belajar secara lebih non-formal afektif dengan tujuan yang dinyatakan secara sadar dan jelas, dan rencana tindakan yang konkret, jelas, tegas, dan lugas.

Kata kunci: bimbingan kelompok; budaya belajar; kabar gembira; Model ABC Tschudi 


\section{PENDAHULUAN}

Budaya belajar meliputi sejumlah sistem keyakinan; komitmen; dan kebiasaan belajar serta berwujud pada perilaku dalam belajar. Bentuk penting budaya belajar yang baik pada mahasiswa adalah reproduksi ilmu atau retrival (retrieval) secara verbal. Retrival adalah suatu fungsi pengembalian informasi yang tersimpan dalam memori subjek ke pembangkit respon dan mengaktifkan respon subjek. Retrival, dengan kata lain, fungsi mengingat isi belajar yang diwujudkan secara umum berupa respon verbal $\sim$ yaitu berbicara yang dilatarbelakangi transformasi dan pemrosesan isi informasi yang dibicarakan. Retrival merupakan salah satu fungsi penting dalam belajar dari Teori Pemrosesan Informasi (Information Processing Theory) oleh Robert Gagne dan sudah dikajiterapkan oleh para pakar psikologi belajar (Critchlow, 2007; Karpicke \& Roediger III, 2007; Khadjooi dkk., 2011; Taber, 2016).

Stimulasi yang dihadapi subjek belajar adalah tertransformasikan dan terproseskan dalam sejumlah cara. Robert Gagne menguraikan transformasi dan proses dimaksud melalui cara-cara penyerapan informasi ke dalam memori jangka-pendek, konversi informasi ke memori jangka-panjang, ke ingatan serta retrival atas informasi (Critchlow, 2007). Beberapa cara dimaksud berlangsung dalam struktur internal dalam mana perubahan-perubahan dapat dikenali, yaitu tampak pada retrival atas informasi, sebagai bukti telah terjadi proses belajar (Critchlow, 2007). Retrival secara verbal atas informasi atau pengetahuan merupakan bentuk penting budaya belajar pada mahasiswa.

Pada sisi lain, budaya belajar yang berwujud retrival juga dipandang sangat penting dalam meningkatkan ingatan jangka panjang. Pernah dilakukan serangkaian eksperimen ketat dalam menguji apakah tes sebagai perangkat belajar dan testing merupakan alat atau cara meningkatkan belajar. Dari eksperimen disimpulkan dua hal: (1) latihan retrival berulang-ulang merupakan cara paling ampuh untuk meningkatkan ingatan jangka panjang, namun demikian; (2) tidak jelas dalam pandangan para siswa dan pendidik bahwa menempuh tes selaku bagian dari perangkat pembelajaran atau penggunaan testing sebagai alat untuk meningkatkan belajar (Karpicke \& Roediger III, 2007). Pada ulasan lain dinyatakan bahwa menempuh testing sebagai bagian dari strategi belajar dapat meningkatkan perhatian (attention) dan kesadaran akan isi ingatan (conscious awareness) sehingga isi ingatan masuk ke dalam memori kerja, working memory, pada diri subjek belajar. Proses-proses itu menunjukkan peran penting perhatian (attention) dan retrival dalam belajar (Schell \& Porter, 2018). Karpicke \& Roediger III (2007) menyatakan bahwa potensial dilakukan penelitian lebih lanjut dalam area ini untuk menguraikan apa jenis teknik-teknik belajar yang dianjurkan bagi para siswa dan pembelajar atau pendidik.

Dalam identifikasi latar belakang permasalahan berdasarkan pengalaman dan penilaian kolega serta kesan mahasiswa bahwa telah dilakukan pembelajaran terhadap mahasiswa Lembaga Pendidikan Tenaga Kependidikan (LPTK) dengan berbagai metode seperti ceramah; modular konvensional; pemberian tugas tertulis; serta model-model mutakhir yang berupaya mengaktifkan subjek belajar. Namun sedikit sekali dimanfaatkan oleh para mahasiswa untuk berlatih retrival secara verbal, berbicara. Gambaran umum kegiatan diskusi kelas dalam pembahasan hasil kerja kelompok menampakkan kurang terinternalisasinya budaya belajar. Hal itu ditandai oleh sangat minimnya tingkat partisipasi retrival verbal mahasiswa baik dari segi jumlah mahasiswa; frekuensi bicara; dan durasi (lama waktu) bicara mahasiswa. Diskusi hasil tugas kelompok dengan kombinasi metode, misalnya belajar dengan mengalami, cascade, belajar tindakan, hanya menggugah sedikit jumlah mahasiswa yang melakukan retrival secara verbal. Mahasiswa yang melakukan retrival pun mengungkapkan pemikirannya melalui satu dua kata, bukan kalimat lengkap.

Ikhwal dinamika pribadi mahasiswa $\sim$ dari pengamatan intensif dalam proses pembelajaran, wawancara mendalam dengan sejumlah mahasiswa, dan diskusi kolegial $\sim$ diketahui adanya suatu budaya belajar yang kurang terinternalisasi. Ini ditandai oleh keengganan mahasiswa berpartisipasi secara verbal dalam diskusi kelas. Keengganan dimaksud bersumber dari penghindaran mengambil tanggungjawab, atau adanya "sumbatan komunikasi" ("communication stoppers") pada mahasiswa untuk berbicara dalam diskusi kelas. Hal demikian adalah berkaitan dengan "pola pemikiran diri" atau konstruk-konstruk pribadi tiap mahasiswa. Ahli-ahli teori konstruk pribadi, khususnya penganut Personal Construct Theory ( $P C P$ ) meyakini keengganan, atau apapun "sumbatan" itu, berasal dari konstruk inti pada individu mahasiswa (Caputi dkk., 2012; Chiari, 2017). Sejumlah pandangan teoretis dari Freud, Lewin, dan Piaget, menunjukkan bahwa konflik intrapersonal merupakan pengalaman multi sisi yang dapat melibatkan konstruk psikologis ganda (Ozkaramanli dkk., 2016). 
Secara konseptual, "konstruk pribadi" didefinisikan oleh George A. Kelly dan pengikutnya sebagai dinamika pemahaman pribadi tiap individu terhadap sebuah tawaran tindakan, dalam mana tiap individu mempersepsi atau menerima, menafsiruraikan, atau menginterpretasikan kejadiankejadian secara subjektif (Chiari, 2017). Konsep Kelly ini sudah pula diuji sebagai hal yang bermanfaat dalam memodifikasi konstruksi-konstruksi pribadi dalam bimbingan jabatan (Paszkowska-Rogacz \& Kabzinska, 2012). Di dalam konsepsi konstruk pribadi dapat terkandung polarisasi aspek-aspek kesamaan - kesenjangan, di samping keuntungan - kerugian suatu tindakan, sebagai unsur-unsur yang mendorong atau sebaliknya mencegah individu berbuat dalam situasi tawaran tindakan tersedia. Polarisasi aspekaspek itu dapat dikelola menuju arah positif sebagaimana diharapkan dengan Model ABC Tschudi, dan sudah dikembangkan oleh sejumlah pengikutnya (Caputi dkk., 2012; Casebow, 2016; Fisher, 2018).

Dalam penerapan Model ABC Tschudi untuk pengubahan konstruksi-konstruksi pribadi mahasiswa, dapat terjadi sejumlah kesulitan mahasiswa dalam mengidentifikasi konstruk pribadi ketika mahasiswa mengisi format dalam model ini. Oleh karena itu, dalam penelitian ini permasalahan difokuskan pertamatama pada kemungkinan kesulitan mahasiswa dalam proses pengerjaan model ini. Kesulitan dimaksud dapat timbul dari sejumlah dilema yang dialami oleh subjek di antara kutub-kutub pilihan (Casebow, 2016; Fisher, 2018).

Model ABC Tschudi dapat disusun khusus dan digunakan oleh dosen atau pembimbing dalam pengajaran yaitu untuk mengidentifikasi konstruk pribadi yang menunjang dan yang menghambat belajar tiap individu. Konstruk-konstruk pribadi itu, kemudian dikelola untuk menginternalisasi budaya belajar mahasiswa, melalui peningkatan retrival mahasiswa dalam diskusi kelas. Secara khusus, model ini mengandung unsur-unsur: A1 (posisi sekarang), yaitu taraf keengganan retrival verbal atau berpartisipasi aktif dalam diskusi; A2 (posisi yang dituju) yaitu aktif retrival verbal dalam diskusi; selanjutnya mahasiswa bersama dosen/pembimbing mengidentifikasi ciri pribadi dalam unsur B1 (kerugian posisi sekarang); dan B2 (keuntungan posisi yang dituju). Terakhir, mahasiswa bersama dosen/pembimbing mengidentifikasi ciri pribadi dalam unsur $\mathrm{C} 1$ (keuntungan posisi sekarang); dan $\mathrm{C} 2$ (kerugian posisi yang dituju). Dalam hal ini, Model ABC Tschudi digunakan untuk membantu mahasiswa mengenal konstruk-konstruk pribadi kunci yang bekerja dalam upaya internalisasi budaya belajar mahasiswa (Caputi dkk., 2012; Tschudi \& Winter, 2012).

Atas dasar pemahaman profil hasil identifikasi konstruk pribadi mahasiswa itu, dalam prosesnya, mahasiswa dapat mengangkat kesadaran budaya diri masing-masing yang dapat secara kuat memotivasi mereka ke arah aktivitas yang dituju (aktif berlatih retrival verbal dalam diskusi). Dalam proses berlatih ini, memungkinkan kesadaran mahasiswa bergerak dari keadaan tidak sadar akan ketidakkompetensian, ke arah kesadaran akan adanya kompetensi (O’Connor \& Seymour, 1993).

Dengan kata lain, Model konstruk pribadi sebagaimana dianjurkan oleh pengikut George A. Kelly, khususnya Model ABC Tschudi, dapat diterapkan dalam rangka menginternalisasi budaya belajar khususnya meningkatkan taraf partisipasi mahasiswa dalam diskusi kelas. Kebutuhan yang muncul adalah perlunya pengembangan "model kelola konstruk pribadi" untuk internalisasi budaya belajar melalui peningkatan taraf retrival verbal (partisipasi diskusi) mahasiswa dalam pembelajaran.

Atas dasar latar belakang di atas ini, khususnya pada bagian-bagian akhir, terdapat tiga tujuan pokok penelitian ini, yaitu mengetahui: (1) kemungkinan kesulitan yang dihadapi oleh subjek dalam mengisi format $\mathrm{ABC}$ Tschudi; (2) konstruk pribadi kunci yang dikenali oleh para subjek dalam posisi sekarang dan posisi yang dituju; (3) hasil internalisasi budaya belajar subjek atas penerapan Model ABC Tschudi.

\section{METODE}

Penelitian ini berlangsung pada situs Universitas Negeri Malang, Fakultas Ilmu Pendidikan, Gedung D2 salah satu ruang kelas yang berada pada sebuah gedung yang dikenal dengan Gedung Kuliah Bersama (GKB) bertingkat empat. Tiap satu ruang kelas tempat pembelajaran yang berukuran sangat bervariasi, dilengkapi dengan kursi-kursi kuliah tunggal $\sim$ dengan lengan alas tulis. Kursi-kursi itu secara mudah dapat diangkat-pindahkan untuk merubah tatanan dan posisi kelas sesuai kebutuhan proses pembelajaran. Sebagaimana ruang kelas pada umumnya, ruang-ruang belajar itu dilengkapi pula dengan meja-kursi dosen dan white-board serta fasilitas proyektor liquid crystal display (LCD). Dengan kata lain, latar kelas dalam mana dilaksanakan proses belajar mengajar untuk penelitian ini adalah bertatanan dan berposisi secara natural sebagaimana aktivitas pembelajaran lazimnya. 
Secara lebih khusus, penelitian dilakukan pada suasana diskusi kelas dalam pembelajaran mata kuliah Konseling Multibudaya dengan jumlah antara 35-45 orang mahasiswa angkatan-angkatan akhir. Dengan kata lain, dari isi kuliah (yang bersifat "hidup" untuk didiskusikan), segi lama studi mahasiswa peserta (yang cukup "siap pengetahuan"), dan segi jumlah peserta (sedang-sedang besarnya), perkuliahan yang diteliti ini merupakan situasi belajar yang favorable untuk aktivitas diskusi kelas dan sangat memungkinkan diteliti secara natural.

Konteks pembelajaran matakuliah yang dideskripsikan di atas dilaksanakan aktivitas diskusi kelas/ akademik baik secara kelompok kecil maupun klasikal, secara natural. Bersamaan dengan itu, diteliti operasi konstruk pribadi individu, anggota kelompok, dalam tataran keterlibatannya pada aktivitas diskusi kelas. Dengan kata lain, penelitian ini mengambil tipe Penelitian Tindakan Kelas (PTK). Dalam pengajaran konseling dan praktik konseling, PTK mempunyai manfaat mengaitkan teori dan praktik.

Pendekatan penelitian yang cocok, sejalan dengan konteks penelitian adalah kualitatif. Penelitian kualitatif berlangsung dalam latar yang diupayakan senatural mungkin, dalam arti tidak ada perlakukan eksperimental terhadap kelas. Varian kualitatif yang sesuai dijalankan, sesuai dengan substansi yang diteliti (ontologi) yaitu medan fenomenal, adalah tipe penelitian fenomenologi. Dari dua varian penelitian fenomenologi $\sim$ yaitu, transendental dan empirik $\sim$ yang cocok digunakan pada penelitian ini adalah varian fenomenologi empirik. Substansi yang diteliti dengan fenomenologi empirik yaitu pengalaman mengenai perasaan yang riil dipahami subjek dengan penekanan pada menemukan deskripsi perasaanperasaan para subjek.

Tujuan khasnya adalah menentukan apa makna suatu pengalaman bagi pribadi yang memiliki pengalaman itu dan yang mampu menyediakan suatu deskripsi komprehensif atas pengalaman itu. Dari deskripsi umum atau universal subjek secara individual itu ditarik makna-makna, dalam kata lain esensiesensi atau struktur dari pengalaman. Pengalaman yang dimaksud di sini adalah perasaan-perasaan yang dituturkan (pandangan diri; penilaian situasi; anggapan mengenai penilaian orang lain terhadap diri), dengan kata lain berupa konstruk-konstruk pribadi secara subjektif. Konstruk pribadi subjektif (umum, universal) para subjek itu kemudian direfleksikan sehingga ditemukan esensi maknanya entah sebagai konstruk pribadi yang mendukung subjek ataupun menghambat subjek melakukan retrival verbal dalam situasi diskusi kelas (Caputi dkk., 2012; Taber, 2016).

Unit analisisnya adalah individual dalam arti analisis dinamika konstruk pribadi perseorangan dari subjek penelitian. Oleh karena penelitian ini bersifat pengembangan, maka subjek penelitian ada dua lapis: pertama adalah "informan" penelitian; kedua adalah "subjek terteliti". "Informan" penelitian adalah subjek kasus yang dijadikan pangkal tolak untuk merefleksikan makna-makna mengenai konstruk pribadi yang akan dipahami. Informan ditetapkan secara snowballing, yaitu diawali dengan berpusat pada satu orang informan atau subjek terteliti, kemudian memungkinkan bertambah menjadi beberapa orang. Prosedur ini ditempuh dalam pengumpulan data melalui wawancara mendalam berkenaan dengan proses-proses bimbingan kelompok.

Kriteria penentuan informan penelitian adalah:(1) subjek teridentifikasi memiliki keengganan retrival verbal dalam diskusi kelas; (2) subjek memahami perasaannya sendiri (terkait dengan konstruk pribadi) dan mahir menuturkan atau mendeskripsikannya secara subjektif; (3) subjek memiliki pemahaman cukup akan perasaan (terkait dengan konstruk pribadi) teman-teman sekelas; (4) subjek cukup verbal dalam suasana informal dan dapat didekati (approachable) serta dapat diakrabi (accessable). Informan akan ditambahkan dalam proses penelitian atau pengumpulan data sejalan dengan perkembangan pemaknaan (refleksi fenomenologis; refleksi editik; dan refleksi transendental) atau abstraksi konstruk pribadi subjek informan.

Penentuan subjek terteliti adalah dengan "purposive sampling". "Subjek terteliti" adalah orangseorang dalam kelas; peserta kuliah; selaku tempat ditransferkannya makna-makna abstrak (hasil refleksi editik dan refleksi transendental) mengenai konstruk pribadi subjek. Terhadap subjek terteliti ini, dilakukan pengkajian proses terjadinya rekonstruksi ("modifikasi") atas konstruk atau faktor penghambat menjadi konstruk atau faktor pendukung keaktifan retrival verbal subjek; atau juga terjadinya rekonstruksi konstruk yang semakin memperkuat konstruk atau faktor pendukung keaktifan retrival verbal subjek. Subjek terteliti dipilih berdasarkan kekhasannya yang ekstrem yaitu kurang retrival dalam diskusi kelas, sebagaimana disarankan dalam sampling purposif bahwa, misalnya, sesuatu kasus dipilih karena kasus itu dipandang lebih ekstrem. 
Teknik pengumpulan data adalah dengan observasi berpartisipasi medium serta wawancara mendalam. Observasi berpartisipasi medium dalam penelitian ini merupakan upaya pencaritemuan yang menghasilkan kejelasan atas sejumlah ide yang mungkin abstrak dari setting lapangan; demikianpun dengan hal-hal yang problematis, akan dapat dibuat deskripsi lebih spesifik atas dasar kajian aktual pada setting penelitian. Adapun peran peneliti dalam observasi ini adalah bahwa peneliti terlibat dalam aktivitas pembelajaran matakuliah Konseling Multibudaya pada Kelas A dan Kelas B, dalam mana dilakukan pengamatan secara langsung di tengah-tengah peneliti melaksanakan proses pembelajaran yang berpadu dengan pengelolaan konstruk pribadi mahasiswa (subjek penelitian). Peneliti sebagai dosen tidak dapat dan tidak perlu berperan selaku mahasiswa (berpartisipasi sempurna) dalam proses penelitian, serta tidak perlu menjangkau kehidupan sehari-hari subjek di luar kelas melainkan hanya berfokus pada kehidupan dalam kelas. Oleh karena itu, taraf partisipasi yang dilakukan adalah taraf medium, atau menengah.

Wawancara mendalam (in-depth interview) dilakukan terhadap subjek individu-per-individu. Ini berlangsung baik di dalam pengisian blangko-blangko model (dalam proses kelompok) oleh informan maupun setelahnya $\sim$ yaitu proses modifikasi konstruk pribadi yang memungkinkan menunjang retrival verbal subjek terteliti. Sebagai teknik penunjang pelaksanaan observasi, wawancara mendalam dilakukan dengan pendekatan rapport, keakraban sepantasnya, jalinan saling percaya, peneliti dan informan/subjek terteliti.

Secara lebih konkret, wawancara mendalam dilakukan dalam upaya mengungkap secara jujur konstruk pribadi subjek. Melalui wawancara mendalam, subjek dapat menceritakan secara jujur "pemikiran-diri", "penafsiran mengenai penilaian orang lain terhadapnya", ataupun label-label lain mengenai diri dan situasi belajar sebagai isi konstruk pribadinya. Konstruk pribadi mana yang dapat dikategorikan, entah yang telah menghambat ataupun telah dan potensial mendukung, keaktifan retrival verbal subjek. Demikian pula dengan upaya mengungkap konstruk-konstruk pribadi yang dapat dijadikan sebagai "pengubah" atau "strategi intervensi" agar para subjek lebih aktif berpartisipasi retrival verbal dalam diskusi kelas. Persyaratan dan prosedur teknis pelaksanaan wawancara mendalam akan dijalankan secara natural.

Kedua teknik itu $\sim$ observasi berpartisipasi medium dan wawancara mendalam $\sim$ dikerahkan untuk pengumpulan data dan proses pelaksanaan pengembangan partisipasi aktif dalam retrival verbal subjek melalui (aplikasi) model ABC Tschudi.

Analisis dilakukan secara fenomenologis, yaitu penafsiran atas tafsiran subjek mengenai situasi dan dirinya, atau memahami pemahaman subjek. Penafsiran bersusun secara refleksif atau interpretation of interpretation demikian itu, sebagaimana disarankan oleh Alvesson \& Sköldberg (2017), dilakukan bertolak pada uraian-uraian verbal informan (interpretasi) mengenai diri; subjek lain; dan situasinya; yang bersangkutan dengan konstruk pribadi. Kemudian interpretasi subjek itu diinterpretasi oleh peneliti untuk menarik makna atau simpulan. Simpulan interpretif dimasukkan ke dalam kerangka Model ABC Tschudi (Chiari, 2017).

Adapun pengujian kebenaran atau credibility proses dan hasil penelitian dilakukan dengan teknik pengecekan anggota atau peserta/subjek penelitian; teknik diskusi peer (peer debriefing); dan triangulasi.

\section{HASIL}

Sejalan dengan permasalahan dan tujuan penelitian, analisis data menghasilkan keterangan deskriptif dan kategoris sebagai berikut:

Pertama, ada pertentangan dan kesenjangan sebagai bentuk kesulitan serta kompromi dan sinkronisasi pemikiran sebagai strategi efektif mengatasi kesulitan dalam mengisi format Model ABC Tschudi. (1) jenis-jenis kesulitan yang dialami oleh para subjek dalam mengisi format dari model ABC Tschudi adalah: (a) pertentangan kognitif dalam menyusun prioritas; (b) pertentangan sikap dalam menyadari dan mengakui kerugian; (c) kesenjangan proyeksi ke depan antara posisi-posisi pilihan, antara pengharapan ke depan dan kenyataan posisi sekarang; (2) cara dan kiat-kiat efektif subjek dalam mengatasi kesulitan atau pertentangan dan kesenjangan konstruksinya adalah: (a) kompromi pemikiran dan sikap melalui imajeri dan komparasi dengan orang lain atas berbagai pertentangan; dan (b) sinkronisasi pemikiran dan sikap melalui refleksi diri dan tindakan nyata atas berbagai kesenjangan. 
Kedua, kecenderungan perubahan konstruksi pribadi kunci subjek adalah intensional dan kesadaran diskursif versus withdrawal dan stagnan. (1) ada kecenderungan perubahan konstruk pribadi kunci ke arah yang lebih produktif (pada subjek dari golongan $\mathrm{T} 1$ = Taraf retrival signifikan berubah); yaitu perubahan yang cenderung konkret bersifat intensional atau berarah-tujuan yang jelas dan disertai dengan kesadaran yang dapat dituturkan alasan, dasar, dan konsekuensinya (kesadaran diskursif); (2) ada kecenderungan perubahan konstruk pribadi kunci ke arah yang lebih non-produktif (khusus golongan $\mathrm{T} 2$ = Taraf retrival tidak signifikan berubah) yaitu bahwa subjek cenderung berlebihan mengontrol-diri, bahkan withdrawal (menarik diri dari keaktifan diskusi) sudah cukup aktif retrival, memilih kurang aktif $\sim$ takut sukses terutama atas pertimbangan sosial-budaya, menjaga perasaan teman, serta takut risiko bekerja dan belajar lebih berat.

Ketiga, ada kategori internalisasi budaya belajar non-formal emosi positif versus kebergantungan sosial, serta kuat fungsi "kabar gembira" versus "bukan kabar gembira" dalam internalisasi budaya belajar subjek. Kategori yang ditemukan ada dua: (1) kelompok yang mendapatkan lebih banyak/sering "kabar gembira" (balikan positif) dalam proses pembelajaran akan melakukan internalisasi budaya belajar secara lebih non-formal afektif (perasaan/emosi positif) disertai dengan tujuan yang dinyatakan secara sadar dan jelas, dan rencana tindakan yang konkret; jelas; tegas; dan lugas; (2) kelompok yang mendapatkan lebih banyak/sering "bukan kabar gembira" (balikan negatif) dalam proses pembelajaran memiliki karakteristik internalisasi budaya belajar dengan kecenderungan subjek untuk memiliki kesalingbergantungan sosial satu sama lain, sehingga subjek memilih untuk mengurangi berpartisipasi atau retrival dalam diskusi kelas. Meskipun ada motivasi untuk retrival namun itu tidak diwujudkan dalam pemikiran dan langkah-langkah tindakan konkret.

\section{PEMBAHASAN}

Pertama, ikhwal kesulitan yang dihadapi oleh subjek dalam mengisi format ABC Tschudi. Adanya kesulitan berupa pertentangan dan kesenjangan sebagaimana disebutkan dalam temuan pertama penelitian ini adalah sejalan dengan pernyataan teoretis terdahulu bahwa memang dapat timbul sejumlah dilema yang dialami oleh subjek di antara kutub-kutub pilihan (Ozkaramanli dkk., 2016). Pertentangan dan kesenjangan posisi, serta solusi efektif yang ditemukan dalam penelitian ini adalah sesuai dengan penjelasan Tschudi \& Winter (2012) yang menyatakan bahwa sejauh ini mereka telah menegaskan "posisi simtom" pada konstruk masalah A sebagai suatu posisi di mana seseorang person, $\mathrm{P}$, menunjukkan pengalaman menyakitkan baginya, dan karenanya ia ingin pindah menuju "posisi yang dituju" atau desired position (DP). Secara implisit sudah dipastikan oleh Tschudi \& Winter (2012) bahwa tidak perlu mempertimbangkan bahwa seseorang akan selalu terpengaruh oleh posisi simtom menuju posisi yang dituju. Hal ini dikarenakan banyak orang yang berada pada situasi posisi simtom tidak mengalami keinginan untuk berubah. Namun, mungkin ada sebagian orang yang mempertimbangkan bahwa kehidupan akan jauh lebih baik jika posisi simtom bisa bergerak jauh dari posisi yang dituju.

Kompromi dan sinkronisasi pemikiran serta sikap merupakan cara efektif yang dinyatakan oleh subjek untuk mengatasi pertentangan dan kesenjangan dalam diri. Secara teoretik, ini adalah fungsi dari kesadaran dalam belajar. Agaknya di sini berlaku konsepsi empat-tahap belajar menurut O'Connor \& Seymour (1993), yaitu: (1) ketidaksadaran pada ketidakmampuan atau unconscious incompetence; (2) kesadaran pada ketidakmampuan atau conscious incompetence; (3) kesadaran pada kemampuan atau conscious competence; dan (4) ketidaksadaran pada kemampuan atau unconscious competence. Dalam proses berpikir serius mengatasi kesulitan atau pertentangan dan kesenjangan dalam diri para subjek telah memungkinkan kesadaran mahasiswa bergerak dari keadaan tidak sadar akan ketidakkompetensian ke arah kesadaran akan adanya kompetensi. Namun, sangat kuat faktor budaya bekerja di sini, dalam mana subjek belajar melakukan komparasi dengan orang lain atas berbagai pertentangan dan pilihanpilihan retrival.

Dengan kata lain, dalam mengatasi kesulitan secara efektif ini perlu adanya dorongan dari pembelajar, sebagai pembimbing, yang memungkinkan subjek belajar mengambil kesempatan untuk keberdayaan diri mereka. Seorang pembimbing yang mendorong subjek belajar untuk berdaya perlu menjalani suatu proses mendukung subjek belajar untuk menyusun makna baru dan melatih kebebasan mereka dalam 
memilih. Maksudnya, jalur yang ditempuh guru untuk memberdayakan siswa adalah melalui suatu proses mendukung orang (para subjek belajar) untuk menyusun makna baru dan melatihkan kebebasan memilih subjek belajar (Al-Shara, 2015; Chuang dkk., 2014).

Kedua, ikhwal kecenderungan perubahan konstruk pribadi kunci para subjek penelitian. Dua temuan penelitian dalam permasalahan kedua ini menyangkut perubahan konstruksi intensional dan kesadaran diskursif versus withdrawal dan stagnan. Salah satu temuan dalam bagian kedua ini adalah mengenai kecenderungan perubahan konstruk pribadi kunci ke arah yang lebih produktif yang ditandai dengan perubahan yang cenderung konkret bersifat intensional atau berarah-tujuan yang jelas, disertai dengan kesadaran yang dapat dituturkan alasan; dasar; dan konsekuensinya (kesadaran diskursif). Dalam hal demikian ini, ada penjelasan teoretis yang menyatakan bahwa meskipun subjek belajar merasakan adanya dilema untuk memilih apakah tetap mempertahankan atau melepaskan suatu gejala yang menjadi penghalang potensi untuk berubah, namun dengan kegigihan subjek belajar untuk tidak memilih pilihan yang dapat merusak diri mereka tersebut, memberikan indikasi yang jelas bahwa subjek belajar konsisten dengan keinginannya untuk berubah (Tschudi, \& Winter, 2012).

Pada temuan kedua dari kecenderungan perubahan konstruk pribadi kunci ini, ada pula perubahan ke arah yang non-produktif yaitu bahwa subjek cenderung berlebihan mengontrol-diri, bahkan withdrawal (menarik diri dari keaktifan diskusi). Golongan ini cenderung stagnan. Hal demikian terjadi karena konstruk pribadi itu merupakan dinamika pemahaman pribadi tiap individu terhadap sebuah tawaran tindakan (Chiari, 2017). Di dalam dinamika pemahaman terhadap tawaran tindakan itu, tiap individu mempersepsi atau menerima, menafsiruraikan, atau menginterpretasikan kejadian-kejadian secara subjektif dengan mempertimbangkan berbagai dimensi (Ozkaramanli dkk., 2016). Terkesan ada definisi diri dan definisi situasi yang bekerja dalam dinamika pemahaman pribadi dan lingkungan. Ini merupakan karakteristik khas budaya "kemandirian timur" yaitu subjek terpengaruh oleh penilaian teman-temannya. Dinamika pemahaman pribadi inilah yang membedakan antara golongan yang nonproduktif dengan dengan golongan yang lebih produktif tadi.

Dalil-dalil Kelly itu adalah sejalan dengan pandangan teoretis lebih baru yang menyatakan bahwa setiap individu mempunyai sistem konstruk (construct system) yang lain-dari-yang-lain; khas; unik; yaitu tatanan hierarkis dari konstruk-konstruk pribadi, mengandung dimensi kesamaan dan kesenjangan (similarity-difference). Konstruksi-konstruksi idiografik tiap manusia terutama berakar dari sejarah unik masing-masing, dan secara serentak menyediakan suatu basis antisipatori bagi tindakan mendatang. Pada setiap hal yang dialami seseorang sekarang akan bekerja pilihan-pilihan: ketika memilih suatu keyakinan, maka menutup keyakinan berlawanan dengan itu. Itu merupakan dinamika dilemma yang dialami setiap individu dalam mengambil keputusan antara berbagai pilihan (Ozkaramanli dkk., 2016).

Ketiga, ikhwal kategori hasil internalisasi budaya belajar subjek atas penerapan Model ABC Tschudi. Dua butir temuan ketiga penelitian ini merupakan fungsi "kabar gembira" versus "bukan kabar gembira" dalam internalisasi budaya belajar. Pembelajaran yang efektif menyarankan proses belajarmengajar integratif dari segi dimensi psikologis subjek belajar, terutama melibatkan kegembiraan belajar sebagai pengaruh dari peran interaktif dalam proses pembelajaran sehingga menyenangkan subjek belajar (Chuang dkk., 2014). Salah satu cara untuk melatih subjek belajar melakukan retrival secara sering dan membuat respon cermat yang potensial mendatangkan balikan positif atau "kabar gembira" adalah dengan pengadministrasian berbagai testing. Subjek belajar yang menempuh tes secara efektif menuntut latihan-latihan belajar efektif, terampil menguraikan konten pengetahuan, atau keterampilan prosedural, dan itu semua memerlukan memori jangka-panjang (Schell \& Porter, 2018). Ini sejalan dengan penelitian lain yang menemukan bahwa subjek yang menerima balikan positif atau kabar gembira mengenai performansinya merespon lebih benar dan lebih cermat, sementara yang menerima balikan negatif bahkan tidak merespon terhadap sinyal yang kuat (Eil \& Rao, 2011). Secara umum, sudah teruji bahwa emosi positif memfasilitasi enkoding dan membantu retrival informasi secara efisien, meskipun pengaruhnya terhadap memori jangka panjang dan jangka pendek tidaklah selalu seragam (Tyng dkk., 2017).

Peran guru atau instruktur untuk menggembirakan subjek dalam kegiatan belajar adalah menggubah dan memimpin-padukan (orchestrating) semua metode dan alat pembelajaran sehingga berpadu menciptakan "melodi", juga memadukan semua segi dimensi psikologis subjek belajar guna menimbulkan kegembiraan dan kesuksesan belajar. Temuan ini mendukung pembuktian terdahulu bahwa suasana 
gembira subjek belajar melalui skenario interaktif dapat meningkatkan performasi belajar (Chuang dkk., 2014). Kegembiraan subjek belajar banyak bergantung pada implementasi sumber-sumber belajar dan gaya mengajar pembelajar (Al-Shara, 2015).

Pada intinya, telah teruji keberfungsian Model ABC Tschudi dalam memodifikasi kontruksikonstruksi pribadi untuk retrival peserta didik dalam proses bimbingan kelompok. Ini juga mendukung pernyataan yang mengungkapkan bahwa penerapan konsep-konsep konstruk pribadi Kelly adalah bermanfaat dalam memodifikasi arah pilihan seseorang dalam bimbingan (Paszkowska-Rogacz \& Kabzinska, 2012).

\section{SIMPULAN}

Pertama, ada kesulitan berupa pertentangan dan kesenjangan dalam kelola konstruk pribadi. Kompromi dan sinkronisasi pemikiran dan sikap merupakan cara efektif yang dinyatakan oleh subjek untuk mengatasi pertentangan dan kesenjangan dalam diri. Ini secara teoretis adalah fungsi dari kesadaran dalam belajar. Pengajar atau pembimbing memiliki peran sangat penting dalam mendorong subjek belajar menyadari kemampuannya, dan untuk berlatih secara terus-menerus sampai tahap subjek belajar tidak lagi menyadari kemampuannya yaitu tataran otomatisasi sebagaimana orang yang berjalan yang tidak lagi menyadari kemampuannya mengangkat kaki secara bergantian. Adalah besar peran budaya dalam belajar retrieval ini yaitu adanya pembandingan diri dengan orang lain dalam penyelesaian berbagai pertentangan. Kedua, kecenderungan perubahan konstruksi pribadi kunci subjek adalah intensional disertai kesadaran diskursif versus withdrawal dan stagnan. Ada perubahan konstruk pribadi kunci ke arah yang lebih produktif dan ada yang ke arah non-produktif. Berlaku proposisi umum dalam sistem konstruk pribadi bahwa ketika terbuka suatu pilihan pada suatu keyakinan dengan penuh kesadaran maka tertutup pilihan pada suatu keyakinan lain yang bertentangan dengan itu. Ada definisi diri dan definisi situasi yang bekerja dalam dinamika pemahaman pribadi dan lingkungan. Ini merupakan karakteristik khas budaya "kemandirian timur". Ketiga, sangat kuat fungsi "kabar gembira" versus "bukan kabar gembira" dalam internalisasi budaya belajar subjek. Pemberian "kabar gembira" (balikan positif) menimbulkan internalisasi budaya belajar secara lebih non-formal afektif dengan tujuan yang dinyatakan secara sadar dan jelas, serta rencana tindakan yang konkret; jelas; tegas; dan lugas. Pemberian "bukan kabar gembira" (balikan negatif) menimbulkan internalisasi budaya belajar ditandai kesalingbergantungan sosial satu sama lain, subjek mengurangi berpartisipasi atau retrival. Meskipun ada motivasi untuk retrival namun itu tidak diwujudkan dalam pemikiran dan langkah-langkah tindakan konkret.

Beberapa saran terkait hasil penelitian antara lain: (1) temuan-temuan berupa proposisi penelitian ini hendaknya dapat digunakan untuk melengkapi penjelasan teoretis mengenai konstruksi pribadi, budaya belajar, dan fungsi "kabar gembira" dalam pembelajaran dan bimbingan atau konseling; (2) format Model $\mathrm{ABC}$ Tschudi yang dikembangkan dalam penelitian ini hendaknya digunakan secara terbatas untuk kalangan mahasiswa saja; (3) jika format Model ABC Tschudi ini perlu digunakan untuk tingkat sekolah menengah atas atau sekolah menengah pertama, hendaknya dilakukan PTK juga sebelumnya.

\section{DAFTAR RUJUKAN}

Al-Shara, I. (2015). Learning and Teaching Between Enjoyment and Boredom As Realized by The Students: A Survey from The Educational Field. European Scientific Journal, 11(19), 146-168.

Alvesson, M., \& Sköldberg, K. (2017). Reflexive Methodology: New Vistas for Qualitative Research. Sage.

Caputi, P., Viney, L. L., Walker, B. M., \& Crittenden, N. (2012). Personal Construct Methodology. New York: John Wiley \& Sons, Ltd., Publication.

Casebow, R. (2016). Working with Resistance to Change 1: The ABC Model. Diambil pada 16 Februari, 2018, dari http://www.edinburghalexandercentre.com/blog/item/72-working-with-resistance-to-change-1-the-abcmodel

Chiari, G. (2017). George A. Kelly and His Personal Construct Theory. Florence, Italy: The George Kelly Society.

Chuang, C.-H., Chen, Y.-N., Tsai, L.-W., Lee, C.-C., \& Tsai, H.-C. (2014). Improving Learning Performance with Happiness by Interactive Scenarios. The Scientific World Journal, 2014, 1-12. https://doi. org/10.1155/2014/807347 
Critchlow, R. (2007). Robert Gagne's Nine Events of Instruction: "Organization is The Hallmark of Effective Instructional Materials.” Diambil 21 Oktober, 2010, dari http://budapest.usembassy.gov/uploads/ images/94KMTTRtqw2d0Ii-AmOyeA/gagnes_nine_events_of_instruction.ppt

Eil, D., \& Rao, J. M. (2011). The Good News-Bad News Effect: Asymmetric Processing of Objective Information about Yourself. American Economic Journal: Microeconomics, 3(2), 114-138. https://doi.org/10.1257/ mic.3.2.114

Fisher, J. (2018). Resistance to Change? The ABC Technique. Diambil 16 Desember, 2018, dari https://www. theabp.org.uk/news/change-resistance-to-change-the-abc-model.aspx

Karpicke, J., \& Roediger III, H. (2007). Repeated Retrieval During Learning is The Key to Long-Term Retention. Journal of Memory and Language, 57(2), 151-162. https://doi.org/10.1016/j.jml.2006.09.004

Khadjooi, K., Rostami, K., \& Ishaq, S. (2011). How to Use Gagne's Model of Instructional Design in Teaching Psychomotor Skills. Gastroenterology and Hepatology from Bed to Bench, 4(3), 116-119.

O'Connor, J., \& Seymour, J. (1993). Introducing NLP Neuro-Linguistic Programming. Psychological Skills for Understanding and Influencing People. California: Harper Collins.

Ozkaramanli, D., Desmet, P. M. A., \& Özcan, E. (2016). Beyond Resolving Dilemmas: Three Design Directions for Addressing Intrapersonal Concern Conflicts. Design Issues, 32(3), 78-91.

Paszkowska-Rogacz, A., \& Kabzinska, Z. (2012). Applications of Kelly's personal Construct Theory to Vocational Guidance. Psychology Research, 2(7), 408-421.

Schell, J. A., \& Porter, J. R. (2018). Applying the Science of Learning to Classroom Teaching: The Critical Importance of Aligning Learning with Testing. Journal of Food Science Education, 17(2), 36-41. https://doi. org/10.1111/1541-4329.12141

Taber, K. (2016). Personal Construct Theory. Diambil 16 Februari, 2018, dari http://people.ds.cam.ac.uk/kst24/ EdResMethod/PCT.html

Tschudi, F., \& Winter, D. (2012). The ABC Model Revisited. Dalam P. Caputi, L. L. Viney, B. M. Walker, \& N. Crittenden (Eds.), Personal Construct Methodology (hal. 89-108). Chichester, UK: Wiley-Blackwell.

Tyng, C. M., Amin, H. U., Saad, M. N. M., \& Malik, A. S. (2017). The Influences of Emotion on Learning and Memory. Frontiers in Psychology, 8, 1454. https://doi.org/10.3389/fpsyg.2017.01454 